laboratory accommodation and equipment as well as $\$ 50$ million over ten years for running costs. Both sums are indexed against inflation, while the hospital administration will be allowed to charge an overhead percentage (within the $\$ 50$ million) equal to that agreed from time to time with NIH.

Under the agreement, the hospital is required to patent all inventions arising from sponsored work, but at Hoechst's expense. The company will be automatically entitled to an exclusive licence for exploitation, but the hospital will be able to take back the rights of exploitation if the company delays for more than three years: the agreement specifies that the director of the new department of molecular biology should be Dr Howard Goodman, who is already in post. One of the potentially contentious points in the agreement is that senior appointments be decided "after consultation with the company". The agreement also requires that those appointed should be "as appropriate" recommended for tenured appointments at Harvard Medical School.

On publication, the agreement requires that the company should be sent a copy of any proposed publication 30 days before

\section{SERC director looks to the future}

Britain must collaborate with its European neighbours if it is to have a stake in building major new research facilities in the future, according to Professor John Kingman who succeeded Sir Geoffrey Allen as chairman of the Science and Engineering Research Council (SERC) on 1 October. Precisely how big and costly a facility will be before international collaboration becomes worth while will depend on SERC's future resources and on the needs of potential collaborators. But if SERC was embarking now on some of the major facilities it agreed in the mid-1970s then international collaboration would almost certainly make sense, according to Kingman.

Indeed, the council is already looking for European partners to help with the construction of the spallation neutron source at the Rutherford Laboratory which, at an estimated cost of $£ 15$ million, is due to come on line during 1984. One possible collaborator is Germany which has considered building a similar facility of its own. But the council has also held discussions with other countries which may wish to use the facility.

SERC's difficulties over building major facilities began in the late 1970 s when its budget failed to keep up with inflation, forcing it to lengthen construction times for major facilities and leading to an inefficient use of resources. Worst affected has been the nuclear structure facility at the Daresbury Laboratory which was originally due to come on line in 1978 . Technical difficulties and a shortage of money at the right time have delayed its commissioning this is sent off for publication, during which period the company will decide whether patentable discoveries are involved: all those employed at the department will be required to sign service agreements declaring that the hospital authorities will be notified of any possibly patentable discoveries. Collaboration with others is permitted, provided that Hoechst's exclusive patent rights are not prejudiced. Consultancy for other companies and organizations is permitted so long as there is full disclosure and discussion with the director of the department.

The agreement also defines the way in which the proceeds from patent exploitation will be shared between the inventors, their department and the hospital at large. The agreement says that royalty percentages negotiated should ordinarily be half those appropriate to commercial agreements, and that royalty income should be deductable from the annual payments to which the company is committed.

The agreement now published is very similar to the outline account of it given to the Gore committee earlier in the year, so it is not obvious why the hospital withheld it from the committee.

until March 1982, although the capital cost (£13.5 million at 1980 prices) has kept roughly in line with inflation. The synchrotron radiation facility also at Daresbury, which was commissioned last June eighteen months behind schedule, has suffered a similar, but less acute problem.

Despite a static budget, however, SERC has had some recent successes. Kingman is particularly impressed with the work of the council's three directorates in encouraging collaboration on engineering research between academics and industry. The council set up its fourth directorate in biotechnology last week (see this page) but Kingman is doubtful that it can afford to set up a fifth in microelectronics unless it can transfer responsibility for those in marine and polymer engineering to industry in general or the Department of Industry in particular.

One of Kingman's major problems will be how to maintain the quality of science in British universities which are suffering an unprecedented cutback in income. Although he is sceptical of government promises to maintain the real value of the science vote, he says that he is determined to maintain spending on research grants and studentships at least at its present level. That could mean convincing the Advisory Board for the Research Councils, which divides the science vote between the five research councils, that SERC should have a larger slice of the cake. It will also mean maintaining numbers in the face of overall cuts in research studentships already made by the Department of Education and Science.
UK biotechnology

\section{Still striving}

The British Science and Engineering Research Council (SERC) last week launched a new directorate to foster collaboration in biotechnology between academics and industry and to forestall any brain drain of British biotechnologists to greener pastures abroad. The new biotechnology directorate is partly a response to a major study, chaired by Dr Alfred Spinks, which recommended nearly two years ago that Britain must act swiftly if it is not to lose out on the commercial development of biotechnology. Contrary to appearances, however, SERC has not been tardy in its response, according to Dr Geoffrey Potter, who will lead the new directorate. SERC's specialist panel on biotechnology spent the past year working out precisely what to do.

The biotechnology directorate will perform a function similar to the existing SERC directorates in polymer and marine engineering except that it will report to both the science board and the engineering board, reflecting the broad spectrum of research that biotechnology encompasses. One of its most difficult tasks, according to Dr Potter, will be to motivate process engineers, notoriously more reluctant than microbiologists to seize opportunities in biotechnology.

The directorate's funds will only be modest, $£ 1$ million this year rising to $£ 2.4$ million by $1984-85$. The extra money will come from the Advisory Board for the Research Councils and from economies in SERC's other activities.

Most of the money will be spent on fostering collaboration through schemes already used by SERC to get industry involved in research in universities. These include the teaching company scheme and Cooperative Awards in Science and Engineering (CASE), both of which support postgraduate students on research projects relevant to collaborating companies, and the cooperative grant scheme whereby SERC and collaborating companies chip in to the cost of research projects in university laboratories.

SERC is particularly keen to encourage collaboration on fermentation, enzyme and immobilized cell technology, separation and concentration technology, product processing and recombinant DNA research. The directorate is to work closely with the Department of Industry which may take over funding of projects approaching the development stage, and with the Agricultural Research Council and Medical Research Council, both of which also support biotechnology.

One of the directorate's aims, according to Dr Potter, is to create sufficient jobs to dissuade British biotechnologists from taking posts in industry and universities abroad and even to persuade those who have already left to return. Dr Potter's concern about a possible brain drain is 